\title{
List of abbreviations and Irish terms
}

\begin{tabular}{|c|c|}
\hline AIA & Anglo-Irish Agreement \\
\hline AIIC & Anglo-Irish Intergovernmental Conference \\
\hline An Phoblacht & $\begin{array}{l}\text { 'The Republic', a republican newspaper supportive } \\
\text { of Sinn Féin }\end{array}$ \\
\hline Ard Chomhairle & the national executives of a political party \\
\hline Ard Fheis & $\begin{array}{l}\text { 'High Assembly', the term used for party } \\
\text { conferences in Ireland }\end{array}$ \\
\hline $\mathrm{BBC}$ & British Broadcasting Corporation \\
\hline B/GFA & Belfast/Good Friday Agreement (1998) \\
\hline $\mathrm{CAB}$ & Cabinet Office \\
\hline Dáil & Lower house of the Oireachtas \\
\hline DFA & Department of Foreign Affairs \\
\hline DT & Department of the Taoiseach \\
\hline DUP & Democratic Unionist Party \\
\hline EEC & European Economic Community \\
\hline Éire Nua & $\begin{array}{l}\text { 'New Ieland', a proposal in the } 1970 \text { s for a federal } \\
\text { United Ireland }\end{array}$ \\
\hline Fianna Fáil & $\begin{array}{l}\text { 'Soldiers of Destiny', one of the major political } \\
\text { parties in Ireland, serving in government from } \\
1957 \text { to } 1973\end{array}$ \\
\hline Fine Gael & $\begin{array}{l}\text { 'Family of Ireland', one of the major political } \\
\text { parties in Ireland, leading a coalition government } \\
\text { with the Labour Party from } 1973 \text { to } 1977\end{array}$ \\
\hline GFA & Good Friday Agreement (1998) \\
\hline HMG & Her Majesty's Government \\
\hline IDU & Inter-Departmental Unit on the North of Ireland \\
\hline
\end{tabular}




$\begin{array}{ll}\text { IRA } & \text { Irish Republican Army } \\
\text { LAW } & \text { Loyalist Association of Workers } \\
\text { MP } & \text { Member of Parliament } \\
\text { NAI } & \text { National Archives of Ireland } \\
\text { NICRA } & \text { Northern Ireland Civil Rights Association } \\
\text { NILP } & \text { Northern Ireland Labour Party } \\
\text { NIO } & \text { Northern Ireland Office } \\
\text { NIPC } & \text { Northern Ireland Political Collection } \\
\text { OE } & \text { Office of the Executive } \\
\text { OIRA } & \text { Official Irish Republican Army } \\
\text { Oireachtas } & \text { Combined name for the Lower house (Dáil) and } \\
& \text { the Upper house (Seanad) of the Irish Parliament } \\
\text { PIRA } & \text { Provisional Irish Republican Army } \\
\text { PRONI } & \text { Public Records Office of Northern Ireland } \\
\text { RTÉ } & \text { Raidió Teilifís Éireann } \\
\text { RUC } & \text { Royal Ulster Constabulary } \\
\text { SDLP } & \text { Social Democratic and Labour Party } \\
\text { Seanad } & \text { Upper house of the Oireachtas } \\
\text { Sinn Féin (Provisional) } & \text { 'We Ourselves', a party supportive of the } \\
& \text { Provisional IRA during the Troubles } \\
\text { SIS } & \text { Secret Intelligence Service } \\
\text { Tánaiste } & \text { the Office of Deputy Prime Minister of Ireland } \\
\text { Taoiseach } & \text { 'Chieftain', used for the office of Prime Minister of } \\
& \text { Ireland } \\
\text { TD } & \text { Teachta Dála, Member of the Dáil } \\
\text { TNA } & \text { The National Archives (UK) } \\
\text { UAC } & \text { Ulster Army Council } \\
\text { UDA } & \text { Ulster Defence Association } \\
\text { UK } & \text { United Kingdom } \\
\text { UN } & \text { United Nations } \\
\text { UPNI } & \text { Unionist Party of Northern Ireland } \\
\text { UUAC } & \text { United Ulster Action Campaign } \\
\text { UUC } & \text { Ulster Unionist Council } \\
\text { UUP } & \text { Ulster Unionist Party } \\
\text { UUUC } & \text { United Ulster Unionist Council } \\
\text { UUUM } & \text { United Ulster Unionist Movement } \\
\text { UVF } & \text { Ulster Volunteer Force } \\
\text { UWC } & \text { Wlst Loyalist Coalition } \\
\text { WBLC } & \end{array}$

